\title{
An Analysis of Students' Science Process Skills in Hydrolysis Subject Matter Using Testlet Instrument
}

\author{
Sri Yamtinah ${ }^{1}$, Mohammad Masykuri $^{2}$, Ashadi $^{3}$, Ari Syahidul Shidiq ${ }^{4}$ \\ Science Education Master Program \\ Universitas Sebelas Maret, Surakarta, Indonesia \\ E-mail: jengtina@staff.uns.ac.id
}

\begin{abstract}
Science process skills could not be separated from the process of conceptual understanding in teaching-learning of science and applied science. The skills needed to be identified and discussed as skills which were implementable in many subjects. The assessment on students' skills was influenced not only by the ability to use these skills, but also by the knowledge of a particular subject in which the skills were used. The aim of this study was to analyse students' science process skills by using Testlet instrument. The science process skills were analysed from 226 students studying in three different schools. The Testlet instrument in this study was designed in the form of multiple choices. The indicators of science process skills in this study consisted of conceptual knowledge, observation, controlling variable, interpreting data and drawing conclusions. The results obtained in this study were that the students' completeness on conceptual knowledge was $71 \%$, on observation was $39.7 \%$, on controlling variable was $29.4 \%$, on interpreting data was $35.7 \%$, and on drawing conclusion was $29.7 \%$.
\end{abstract}

Keywords: science process skills; testlet; assessment instrument

\section{INTRODUCTION}

Science learning and development of science process skills are two integrated things [1]. Every educational system should provide a scientific culture that enables every student to succeed in adapting to modern society [2]. Science process skills make science learning easier, increase the students' activities, and increase the students' responsibility toward learning they conduct. Those skills teach the students scientific methods or researches $[3,4]$. They are interdisciplinary and suitable for every field of science. The importance of the skills for the students include how to learn to implement sciences in real learning and in everyday life, how to apply concepts, how to generate theories and rules in learning [3,5].

The science process skills are considered to be efficient and significant in learning programs in some places [6]. In science education, teachers play role to facilitate the learning process so that the students can participate actively, integrate science to life, make learning meaningful, and improve science process skills as well as be responsible for the learning they do [7,8]. For this purpose, educational experts have suggested several approaches, methods, and techniques used to streamline science learning $[3,9]$. 
Science process skills will be scientific when they are implemented to the content of science in the learning. The skills relate to the entire content of science in learning [9]. Learning science without using an assessment based on the science process skills will be easily forgotten by the students and will be meaningless $[5,6,10]$

An analysis on the relationship between hierarchical concepts of cognitive reasoning and integrated science process skills was conducted by Yeany, Yap and Padilla [11]. The result shows that there was a positive relationship between the concepts of cognitive reasoning and the integrated science process skills. Students will not get certain science process skills until they fulfil cognitive skill requirements.

The science process skills can be classified into 2 types, namely: basic and integrated ones [12]. The basic science process skills include observation, measuring, inferring, classifying, predicting, using numbers, investigating the relationship between time and space as well as presenting data. The integrated science process skills include manipulating and interpreting data, controlling variables, defining operationally, formulating a hypothesis, and experimenting [2,13]. Thailand has implemented teaching standard for the science process skills which cover 13 aspects, namely: observation, classifying, measuring, using numbers, finding out the relationship between time and space, inferring, predicting, communicating, controlling variables, determining operational variables, formulating a hypothesis, experimenting, interpreting data, and drawing conclusions [14]. In another study, the indicators of integrated science process skills are defined. They include making a hypothesis, defining operational variables, designing experiments, and interpreting data to master subject contents [8].

In addition Shahali and Halim defined indicators on science process skills, which include five aspects, namely: formulating a hypothesis, controlling variables, defining operational variables, interpreting data, and designing experiments [6]. Meanwhile in their research Hodosyova et al. measured 4 science process skills, namely: conceptual knowledge, making a research plan, interpreting results, and drawing conclusions [5].

Based on various definitions of science process skills and several indicators on science process skills described above, the indicators of the science process skills used in the study based on the research conducted by Shidiq, Yamtinah, and Masykuri [15], namely: conceptual knowledge, observation, controlling variables, interpreting data and drawing conclusions.

The science process skills are not a specific subject, but they foster the specific knowledge subject. There should be a task, some information to note, or a problem to solve so that the skills are implementable [16]. Assessing the process skills without including concept understanding that the students have is not valid $[6,9,10]$. Therefore, it is important to do an assessment on the process skills containing conceptual knowledge or specific subject used in the process skills. In any case, the assessment on the skills is not influenced only by the ability to use these skills, but also by the knowledge of a particular subject in which the skills are used. Assessment instrument that can be used to measure science process skills in specific subject is Testlet. It is an instrument that has more than one response and can be designed hierarchical based on specific subject used $[16,17]$. Accordingly the aim of this study is to analyse the students' science process skills using testlet instrument in hydrolysis subject matter. 


\section{RESEARCH METHODOLOGY}

The objects of this study were 226 students of three different representative schools. The representative schools were public and private ones with the high, medium and low levels of achievement. Paper and pencil tests were performed using the instrument of Testlet. The test was conducted two times namely main field test and operational field test; both tests are the part of research and development cycle [18]. The first test was given to 75 students and the second test was given to 151 students. These two tests aimed to show the use of testlet instrument consistency. A total of 30 items in the form of Testlet multiple choice questions were used to investigate the students' science process skills. The indicators of the science process skills and the composition of items utilized in it were based on the research undertaken by Shidiq, Yamtinah, and Masykuri [15]. The distribution of items based on the indicators of the science process skills is presented in Table I.

TABLE I. DISTRIBUTION OF ITEMS

\begin{tabular}{|cccc|}
\hline No & SPS indicators & Item Number & Number of Item \\
1 & Conceptual knowledge & $1,4,7,10,16,2228$, & 7 \\
2 & Observation & $8,11,14,20,29$ & 5 \\
3 & Controlling variables & $6,12,17,23,25,26$ & 6 \\
4 & Interpreting data & $2,5,13,19,21$ & 5 \\
5 & Making conclusions & $3,9,15,18,24,27,30$ & 7 \\
\hline
\end{tabular}

\section{RESULTS}

\section{Students' Science Process Skills on Main Field Testing}

On the main field testing, the instrument was tested to a class of students in each school with the total number of 75 students. The results of the test are presented in Table II.

TABLE II.COMPLETENESS OF SPS INDICATORS ON MAIN FIELD TESTING

\begin{tabular}{|lcccc|}
\hline \multicolumn{1}{|c}{ Indicators } & $\begin{array}{c}\text { High-category } \\
\text { school }\end{array}$ & $\begin{array}{c}\text { Percentage of Completeness } \\
\text { Medium- } \\
\text { category school }\end{array}$ & $\begin{array}{c}\text { Low-category } \\
\text { school }\end{array}$ & Total \\
Conceptual knowledge & 80.6 & 78.1 & 56.3 & 74.1 \\
Observation & 51.4 & 66.0 & 50.6 & 57.1 \\
Controlling variables & 61.9 & 31.7 & 17.6 & 39.7 \\
Interpreting data & 41.4 & 42.0 & 27.1 & 38.4 \\
Drawing conclusions & 55.6 & 34.8 & 28.6 & 41.1 \\
\hline
\end{tabular}

Table II illustrates the percentage distribution pattern which was almost the same. In each school the indicators of conceptual knowledge and observation got the highest percentage. This proves that the students actually learned the basic concepts of the hydrolysis reaction and could observe and distinguish the hydrolysis reaction. However, the indicators of controlling variables, interpreting data and drawing 
conclusions in almost all schools at the lowest percentage, especially the indicator on interpreting data. This might be because the students only understood the basic concepts of salt hydrolysis material. However, when the students encountered a new question item in which they had to identify influencing variables, interpret data and draw conclusions from all available information before, they found difficulties. The results of the test were useful to categorize the students based on their science process skills. In this study, the students were classified into 3 types, namely: students with high, medium and low SPS. The students' SPS percentage in each school is presented in Figure 1.

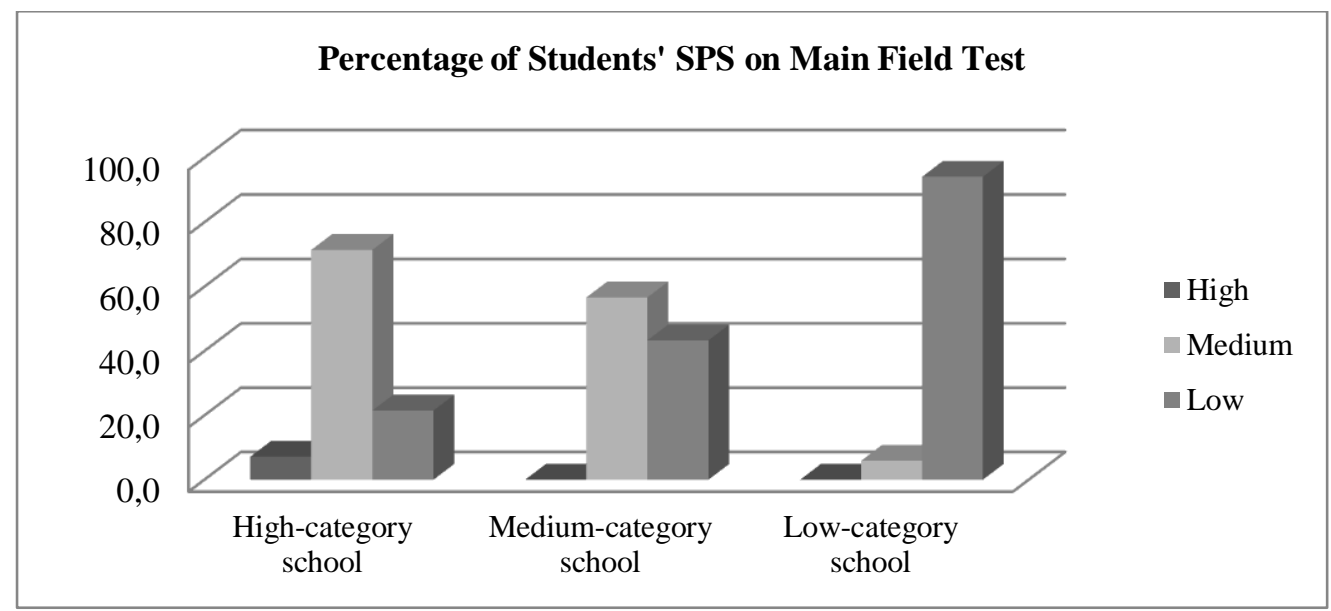

Figure 1.Percentage of students' SPS on Main Field Test

\section{Students' Science Process Skills on Operational Field Testing}

On the operational field testing, the instrument was tested to two classes of students in each school. The total number of the students was 151 . The results of the test imply that in addition to item analysis, this test could also be used to identify the students' SPS. The results analysis on this test is presented in Table III.

TABLE III.COMPLETENESS OF SPS INDICATORS ON OPERATIONAL FIELD TESTING

\begin{tabular}{|lcccc|}
\hline \multicolumn{1}{|c}{ Indicators } & $\begin{array}{c}\text { Percentage of completeness } \\
\text { High-category } \\
\text { school }\end{array}$ & $\begin{array}{c}\text { Medium- } \\
\text { category } \\
\text { school }\end{array}$ & $\begin{array}{c}\text { Low- } \\
\text { category } \\
\text { school }\end{array}$ & Total \\
Conceptual knowledge & 61.4 & 75.8 & 73.0 & 69.9 \\
Observation & 47.4 & 33.1 & 40.9 & 40.8 \\
Controlling variables & 32.5 & 22.8 & 30.4 & 28.7 \\
Interpreting data & 41.4 & 31.8 & 33.3 & 35.9 \\
Drawing conclusions & 37.1 & 18.7 & 33.3 & 29.9 \\
\hline
\end{tabular}


TABLE IV.TOTAL COMPLETENESS OF SPS INDICATORS

\begin{tabular}{|lc|}
\hline \multicolumn{1}{|c}{ Indicators } & Percentage of Completeness \\
Conceptual knowledge & 71.0 \\
Observation & 46.2 \\
Controlling variables & 32.4 \\
Interpreting data & 36.7 \\
Drawing conclusions & 33.7 \\
\hline
\end{tabular}

Table III which was the results of the operational field testing and Table IV which indicated the total data on the SPS testing of the 226 students show that the results of the testing only had few differences from those of the testing of the former phase. The indicator mastered most by students was conceptual knowledge while other indicators in each school provided almost the same proportion. The results which were almost the same with the previous ones proved that the students' science process skills still occupied the low level i.e. understanding concept only. The students understood the basic concepts of hydrolysis but did not have enough skills to manage and utilize their knowledge in more complex problems. This led to the less good results on the indicators of identifying variables and drawing conclusions. The distribution of the categorized students in each school is presented in Figure 2.

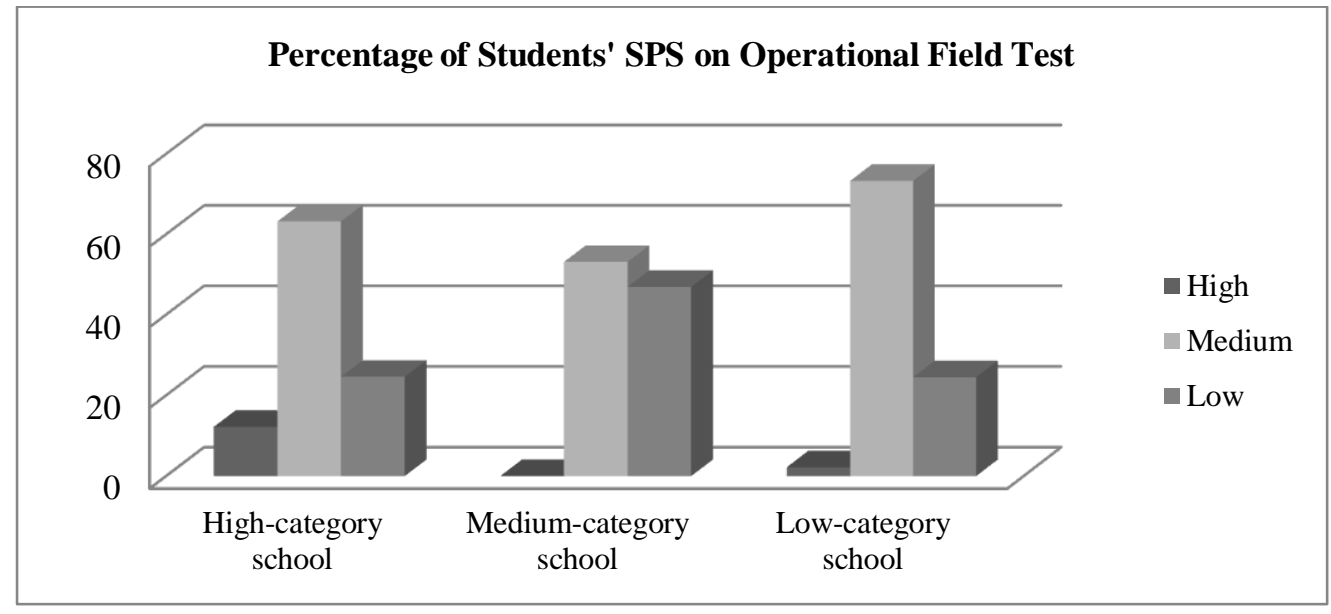

Figure 2.Percentage of Students' SPS on Operational Field Test

Figure 2 shows that on the second testing, the operational field testing, the good categorized schools had a larger percentage of students with the high categorized SPS more than the other categorized schools. This proved that the good teaching by teachers and good intakes would create students with a good SPS anyway. The students of the high categorized schools were more frequently given exercises and learning, which trained the science process skills. As a result, the results in this test indicate that the students of the high categorized schools had a better SPS than other students of the other categorized schools. On the contrary, the tests in medium categorized schools (represented by private schools) provided no better results than those in low categorized schools. These less good results might be caused by various factors, including the students' internal factors. 


\section{DISCUSSION}

\section{Testing of Science Process Skills}

Dillashaw and Okey [8] developed the test of the integrated science process skills for secondary science students and concluded that science teachers needed a means of measuring process skill competency that could be administered efficiently and objectively. Therefore, a decision was made to utilize a paper-and-pencil group testing format. The whole 36 multiple-choice test items with four alternatives were written. The science process skills selected for testing were those associated with planning, conducting, and interpreting results from investigations. Usually it was referred to as the integrated science processes including formulating hypotheses, operationally defining, controlling and manipulating variables, planning investigations, and interpreting data.

Shahali and Halim [6] conducted a study on the development and validation of a test of integrated science process skills that developed 30 multiple choice questions with 5 indicators of science process skills. The testing of items in the study was carried out on 101. The results of the tests were then analysed in terms of their reliability, validity, difficulty level, differentiability, and distracter index. It was intended for reference to question revision.

Germann [19] conducted a study on the testing of science process skills model in Biology. This study furthered the effort to examine the relationships and causal effects on the learning of science process skills, and Biology knowledge was used as a variable because the science process skills were context dependent. In addition, the research on science process skills tests have also been carried out. One of them was conducted by Molitor and George [20] on the development of a test of science process skills. They developed science process skills tests including collecting data, analysing and using information to solve the problem. The test was developed for students in Grades Four, Five and Six. The conclusion was not all indicators of science process skills gave good results. The students tended to give good results when the indicators were related "recall" process and conceptual knowledge but did not give good enough results to collect and connect data. Roth and Roychoudhury [4] conducted a study on the development of science process skills in authentic contexts and concluded that the use of open-ended inquiry laboratories for students in Grade 8 science and Grades 11 and 12 physics resulted in the development of higher-order process skills such as identifying variables, interpreting data, hypothesizing, defining, and experimenting.

Tobin and Capie [21] conducted a study on the development and validation of a group test of integrated science processes and concluded that a 24 -item paper and pencil test could be administered to groups of students to obtain measures of process skill acquisition to use by classroom practitioners and researchers. Because the items measure performance on objectives that could readily be translated into classroom activity, the test had direct applicability to classroom-based research and evaluation of instruction and learning.

Burns, Okey, and Wise [22] conducted a study on the development of an integrated process skill test. The advantage of the research was that the test was not specific to a given curriculum or content area, so it might be used across the various disciplines of science. The test reflected the students' ability to apply the logic 
required to conduct fair investigations. In addition to assessing process skills competence of secondary students, the test might also be a useful tool in teacher education programs. Prospective secondary and elementary teachers needed to exhibit process skills competence in order to effectively teach science. A third use of the test would be in the evaluation of curricula or materials that had a process orientation.

\section{Improving Science Process Skills}

Based on the result of this study, there are no significant results of highcategorize students' science process skill in all three different schools. Moreover, only conceptual knowledge indicator that has good score in two stages of test. Science process skills can be trained and taught to the student through various approaches, methods, media, and evaluation instruments. For example, the teachers should train the students to always think scientifically and give them exercises on the SPS to practice their science process skills. Based on the research conducted by Lati, Supasorn, and Promarak [12], inquiry approach was proven to be an effective learning approach to improve the conceptual understanding, critical thinking skills, and science process skills in Thailand. Inquiry is the most effective approach to improve the students' science process skills. This step is suggested so that teachers can expect a lot of improvement in the students' ability after practicing several experiments. Moreover students need several opportunities to improve their skills in various contexts.

Karamustafaoglu [3] explains that the science process skills facilitated the science learning and students' activities, increased the students' responsibility for their learning, and teach the students about scientific methods or research. Besides, these skills are also useful to think about how to get information, to think about problems and to formulate conclusions. These skills are suitable for all fields of science. The important thing for the students is how to learn to implement sciences in real learning and in everyday life, to apply concepts and to generate theories and rules in learning. The students need them more to familiarize themselves in the science process skills.

The science process skills are considered to be efficient in learning and significant learning programs in some places. In science education teachers intend to facilitate the students according to the needs in the learning process so that the students can actively participate, integrate science with life, make learning meaningful and improve science process skills as well as be responsible for their learning. For this purpose a number of approaches, methods, and techniques are used to streamline the learning. This is based on the suggestions from education experts. It aims at helping the students and teachers to carry out learning process in the right way, to relate learning to everyday life, to reveal the student's knowledge obtained previously, and to transfer new knowledge or research questions at the end of learning. Thus, the science process skills may improve.

Researches on teaching science process skills have frequently been conducted. One of them was conducted by Ambross, Meiring, and Blignaut [23]. They did research on the implementation and development of science process skills in the natural sciences. The results of this research recommend that the government or any educational institution needed to support teachers, for instance, by holding 
workshops to improve the teachers' understanding on science process skills. Gezer [7] conducted a case study on the pre-service science teachers' laboratory usage selfefficacy and scientific process skills that led to the conclusion that inquiry and research based learning environments could improve science process skills more than the laboratory traditional courses.

Kurea and Thongperm [14] conducted a study on the status, support and obstacles in learning science process skills in Thailand. This study provided a conclusion that the best support came from teachers' confidence to teach science process skills in the classroom while a significant obstacle in implementing science process skills in the classroom was timing. The students could not concentrate to understand the learning in a state of limited time. They did not have enough time to think and discuss seriously to improve experimental design and desired results.

Keil, Haney, and Zoffel [24] conducted a study to improve students' achievements and science process skills using Environmental Health Science Problem-Based Learning Curricula. Science process skills test in this study used 21 questions. The test was developed to evaluate integrated science process skills such as: designing experiments, using variables, presenting data, and interpreting data. Lavoie [25] investigated effects of emphasizing hypothetic-predictive reasoning within the science learning cycle on high school student's process skills and conceptual understandings in Biology; Foulds and Rowe [1] conducted a study on the enhancement of science process skills in primary teacher education students who stated that the programs provided a level of science process skills which was completely adequate for learning.

\section{CONCLUSIONS}

This study shows that the teachers' inability to assess the science process skills contextually or performance tests may be replaced by assessments on the SPS using a paper and pencil test. This test is designed to give issues which are close to students' lives like presenting problems in the laboratory and environmental issues in everyday life. This means that a given test can be contextual. By linking relating environmental problems with the school learning, the students are expected to be more critical and be able to implement science process skills to solve environmental problems.

A total of 30 items was tested to 226 students in Surakarta. The results show that students still did not have good science process skills in chemistry. The relationship between the subject content with science process skills is important to study because the students can implement science process skills in certain contexts where cognitive knowledge on a subject takes a role. Based on the five indicators analysed in this study, the results of this research show that students' completeness in the indicators of conceptual knowledge, observation, controlling variables, interpreting the data, and drawing conclusion were $71.0 \%, 46.2 \%, 32.4 \%, 36.7 \%$, and $33.7 \%$ respectively. The students' science process skills of the high schools in Surakarta still need to improve. These skills can be improved by using approach, method, media and evaluation instrument such as Testlet that stimulates the formation of science process skills during the learning process. 


\section{REFERENCES}

[1] Foulds, W \& J. Rowe. 1996. "The Enhancement of Science Process Skills in Primary Teacher Education Students", Australian Journal of Teacher Education, 21(1):16-23. doi: 10.14221/ajte.1996v21n 1.2

[2] Aydin, A. 2013. "Representation of Science Process Skills in the Chemistry Curricula for Grades 10, 11 And 12 Turkey, International Journal of Education and Practice, 1(5):51-56.

[3] Karamustafaoglu, S. 2011. "Improving the Science Process Skills Ability of Science Student Teachers Using I Diagram”, Eurasian Journal of Physics \& Chemistry Education, 3(1):26-38. doi: 10.12973/ejpce.2009.00023a

[4] Roth, W. M. \& A. Roychoudhury. 1993. "The Development of Science Process Skills in Authentic Contexts", Journal of Research in Science Teaching, 30(2):127-152. doi:10.1002/tea.3660300203

[5] Hodosyova, M., J. Utla., M. Vanyova., \& V. Lapitkova. 2015. “The Development of Science Process Skills in Physics Education", Procedia Sosial and Behavioral Sciences, 186:982-989. doi: $10.1016 /$ j.sbspro.2015.04.184

[6] Shahali, E. H. M., \& L. Halim. 2010. "Development and Validation of a Test of Integrated Science Process Skills", Procedia Social and Behavioral Sciences, 9:142-146. doi:10.1016/j.sbspro.2010.12.127

[7] Gezer, S. U. 2015. "A Case Study on Preservice Teacher Laboratory Usage Self Efficacy and Scientific Process Skills”. Procedia Social Behavioral Science, 174:1158-1165. doi: 10.1016/j.sbspro.2015.01.732

[8] Dillashaw F. G. \& J. R. Okey. 1980. "Test of The Integrated Science Process Skills for Secondary Science Students". Science Education Journal, 64(5):601-608. doi: 10.1002/sce.3730640506

[9] Harlen, W. 1999. "Purposes and Procedures for Assessing Science Process Skills", Assessment in Education, 6(1):129-144. doi: 10.1080/09695949993044

[10] Harlen, W. 2013. Assessment \& Inquiry - Based Science Education: Issues in Policy and Practice. Trieste: The Global Network of Science Academies Science Education Programme.

[11] Yeany, R. H., K. C. Yap \& M. J. Padilla. 1986. "Analyzing Hierarchiral Relationship among Modes of Cognitive Reasoning and Integrated Science Process Skills", Journal of Research in Science Teaching, 3(4):277-291. doi: 10.1002/tea.366023040

[12] Lati, W., S. Supasorn., \& V. Promarak. 2012. "Enhancement of Learning Achievement and Integrated Science Process Skills Using Science Inquiry Learning Activities of Chemical Reaction Rates". Procedia Social and Behavioral Sciences, 46:4471-4475. doi: 10.1016/j.sbspro.2012.06.279

[13] Brotherton, P., N. \& P. F. W. Preece. 1995. "Science Process Skills: Their Nature and Interrelationships". Research in Science and Technological Education, 13(1):5-11 doi: 10.1080/0263514950130101

[14] Kurea, N., \& O. Thongperm. 2014. "Teaching of Science Process Skills in Thai Contexts: Status, Supports and Obstacles", Procedia Social and Behavioral Sciences, 141:1324-1329. doi: 10.1016/j.sbspro.2014.05.228

[15] Shidiq, A. S., M. Masykuri., \& S. Yamtinah. (2016, May). Assessing science process skills using testlet instrument. International conference on educational research and evaluation, Yogyakarta State University, Yogyakarta.

[16] Yamtinah, S., M. Masykuri., Ashadi., \& A. S. Shidiq. 2017. “Gender Differences in Students' Attitudes toward Science: An Analysis of Students' Science Process Skill using Testlet Instrument", AIP Conference Proceedings, 1868(030003):1-6. doi: 10.1063/1.4995102

[17] Thissen, D., \& H. Wainer. 2001. Test Scoring. Lawrance Erlbaum, Mahwah, pp. 173-174

[18] Borg, W. R., \& M. D. Gall. 1983. Educational Research Fourth Edition. New York, Longman, pp. 624-625

[19] Germann, P. J. 1994. "Testing a Model of Science Skills Acquisition: An Interaction with Parents' Education, Preferred Language, Gender, Science Attitude, Cognitive Development, Academic Ability, and Biology Knowledge", Journal of Research in Science Teaching, 3(7):749-783. doi: 10.1002/tea.3660310707

[20] Molitor, L. L., \& K. D. George. 1976. "Development of A Test of Science Process Skills", Journal of Research in Science Teaching, 13(5):405-412. doi: 10.1002/tea.3660130504 
[21] Tobin K. G. \& W. Capie. 1982. "Relationships between Formal Reasoning Ability, Locus of Control, Academic Engagement and Integrated Process Skill Achievement", Journal of Research in Science Teaching, 19(2):113-121. doi: 10.1002/tea.3660190203

[22] Burns, J. C., J. R. Okey., \& K. C. Wise. 1985. "Development of An Integrated Process Skill Test: TIPS II", Journal of Research in Science and Teaching, 22(2):169-177. doi: 10.1002/tea.3660220208

[23] Ambross, J., L. Meiring., \& Blignaut. 2014. "The Implementation and Development of Science Process Skills in the Natural Sciences: A Case Study of Teachers' Perceptions", Africa Educational Review, 11(3):459-474. doi: 10.1080/18146627.2014.934998

[24] Keil, C., J. Haney., \& J. Zoffel. 2009. "Improvements in Student Achievement and Science Process Skills Using Environmental Health Problem-Based Learning Curricula”, Electronic Journal of Science Education. 13(1).

[25] Lavoie, D. R. 1999. "Effects of Emphasizing Hypothetico-Predictive Reasoning within The Science Learning Cycle on High School Student's Process Skills and Conceptual Understanding in Biology, Journal of Research in Science Teaching, 36(10):1127-1147. doi: 10.1002/(SICI)1098-2736(199912)36:10 